\title{
Respon beberapa varietas Kedelai (Glycine max L. Merr) terhadap tingkat salinitas air penyiraman
}

\author{
(Response of Soybean varieties (Glycine max L. Merr) to water salinity level) \\ S. R. Yunita, Sutarno, dan E. Fuskhah \\ Agroecotechnology, Faculty of Animal and Agricultural Sciences, Diponegoro University \\ Tembalang Campus, Semarang 50275 - Indonesia \\ Corresponding E-mail: sheilarahmayunita@gmail.com
}

\begin{abstract}
The objective of this research was to study the hardiness of several soybean varieties to different levels of water salinity and to find out the effect of salinity on soybean growth and production. This research was conducted in Greenhouse and Laboratory of Ecology and Plant Production at Faculty of Animal and Agricultural Sciences, Diponegoro University from February to May 2017. The research was arranged using completely randomized factorial design with the first factor was soybean varieties (Dering 1, Demas 2, and Devon 3$)$ and the second factor was water salinity level $(0 \mathrm{dS} / \mathrm{m}, 3 \mathrm{dS} / \mathrm{m}, 6$ $\mathrm{dS} / \mathrm{m}$ and $9 \mathrm{dS} / \mathrm{m}$ ). The result showed that the treatment of $3 \mathrm{dS} / \mathrm{m}$ water salinity level did not affect at plant height and number of leaves until 4th week. However salinity of 6 and $9 \mathrm{dS} / \mathrm{m}$ decreased the height and number of leaves from all varieties. Salinity level of 3, 6 and $9 \mathrm{dS} / \mathrm{m}$ decreased the number of pod, weight of pod and 100 seeds weight from all verieties. Dering 1 yielded 100 seeds weight heavier than Demas 1 and Devon 1.
\end{abstract}

Keywords : growth, production, salinity, soybean.

\begin{abstract}
ABSTRAK
Penelitian ini bertujuan untuk menguji ketahanan beberapa varietas kedelai baru terhadap tingkat salinitas air siraman yang berbeda dan mengetahui pengaruh salinitas terhadap pertumbuhan dan produksi kedelai. Penelitian dilakukan di greenhouse dan Laboratorium Ekologi dan Produksi Tanaman Fakultas Peternakan dan Pertanian Universitas Diponegoro, Semarang pada bulan Februari - Mei 2017. Penelitian disusun menggunakan rancangan acak lengkap factorial dengan faktor pertama adalah tingkat salinitas air penyiraman $(0 \mathrm{dS} / \mathrm{m}, 3 \mathrm{dS} / \mathrm{m}, 6 \mathrm{dS} / \mathrm{m}$ dan $9 \mathrm{dS} / \mathrm{m})$ dan faktor kedua adalah varietas kedelai (Dering 1, Demas 1, dan Devon 1). Hasil penelitian menunjukkan tingkat salinitas $3 \mathrm{dS} / \mathrm{m}$ tidak mempengaruhi pertumbuhan tinggi tanaman dan jumlah daun kedelai sampai minggu ke 4. Namun salinitas 6 dan $9 \mathrm{dS} / \mathrm{m}$ menurunkan pertumbuhan tinggi tanaman dan jumlah daun oada semua jenis kedelai yang dicobakan. Penyiraman 3, 6 dan $9 \mathrm{dS} / \mathrm{m}$ menurunkan jumlah polong, berat polong dan bobot 100 biji pada semua kedelai yang dicobakan. Varietas Dering1 menghasilkan bobot 100 biji lebih berat serta signifikan dibanding varietas Demas 1 dan Devon 1.
\end{abstract}

Kata kunci : kedelai, pertumbuhan, produksi, salinitas.

\section{PENDAHULUAN}

Kedelai (Glycine max L. Merr) merupakan salah satu sumber protein nabati yang populer dan menempati urutan ketiga komoditas pangan penting setelah padi dan jagung bagi masyarakat Indonesia. Program swasembada kedelai menjadi salah satu sasaran strategis Kementerian Pertanian tahun 2015-2019. Kedelai popular dimanfaatkan sebagai bahan baku pembuatan tempe dan tahu. Berdasarkan survei nasional tahun 2015 oleh Badan Pusat Statistik (BPS), konsumsi rata-rata tempe setiap orang di Indonesia sebesar 6,99 $\mathrm{kg} / \mathrm{tahun}$ dan konsumsi tahu $7,51 \mathrm{~kg} / \mathrm{tahun}$, 
meningkat dari tahun sebelumnya yaitu 6,95 $\mathrm{kg} /$ tahun tempe dan 7,07 kg/tahun tahu. Selain itu juga dimanfaatkan sebagai bahan pembuatan tauco, kecap dan susu kedelai. Indonesia menjadi pasar kedelai terbesar di Asia. Tingginya kebutuhan kedelai nasional belum diimbangi dengan produksi nasional. Rata- rata produksi kedelai nasional tahun 2011-2015 adalah sebesar 885.000 ton, sedang kebutuhan mencapai 2.946.000 ton setiap tahun, sehingga mengalami defisit sebesar 2.061.000 ton. Impor menjadi alternatif demi pemenuhan kebutuhan kedelai di Indonesia. BPS mencatat volume impor kedelai selama tahun 1980-2015 mengalami pertumbuhan rata-rata $18,62 \%$ per tahun. Untuk meningkatkan produksi kedelai nasional berbagai upaya dapat dilakukan salah satunya dengan perakitan varietas unggul.

Setiap tahun luas lahan pertanian optimal di Indonesia semakin berkurang akibat adanya cekaman biotik maupun abiotik dan konversi lahan pertanian menjadi lahan non pertanian. Pemanfaatan lahan sub optimal menjadi lahan pertanian dapat menjadi alternatif yang dilakukan. Salah satunya pemanfaatan tanah salin menjadi lahan pertanian. Indonesia merupakan negara kepulauan yang memiliki garis pantai sepanjang $95.181 \mathrm{~km}$ dengan potensi luas lahan mencapai 951.810 ha. Lahan salin banyak dijumpai di daerah dekat pesisir pantai akibat pengaruh intrusi air laut. Luas lahan salin di Indonesia mencapai 440.300 ha (Rachman et al., 2007). Pengembangan kedelai di tanah salin menemui kendala dimana belum adanya varietas yang secara resmi dilepas memiliki ketahanan terhadap salinitas.

Salinitas merupakan suatu ancaman dalam upaya produksi kedelai. Akumulai ion $\mathrm{Na}^{+}$ menjadi penyebab utama kerusakan tanaman pada cekaman salinitas (Jouyban, 2012). Pada kondisi salinitas tinggi terjadi penghambatan penyerapan $\mathrm{K}^{+}$yang merupakan nutrisi utama dalam tanaman (Taufiq, 2014). Salinitas menyebabkan kedelai mengalami penurunan tingkat perkecambahan, nekrosis daun, berkurang warna hijau daun, dan menurunankan jumlah nodul yang berdampak pada menurunnya biomassa tanaman, tinggi tanaman, ukuran daun, hasil biji, kualitas biji dan kemampuan tumbuh (Krisnawati dan Adie, 2009). Ambang batas untuk mendeteksi toleransi salinitas kedelai adalah 3,2 $\mathrm{dS} / \mathrm{m}$ (Chinnusamy et al., 2005). Batas kritis salinitas pada pertumbuhan tanaman kedelai adalah $5 \mathrm{dS} / \mathrm{m}$ (Kristiono et al., 2013).

Tujuan dari penelitian ini adalah menguji ketahanan beberapa varietas kedelai baru terhadap tingkat salinitas air siraman yang berbeda dan mengetahui pengaruh salinitas terhadap pertumbuhan dan produksi kedelai.

\section{MATERI DAN METODE}

Penelitian dilaksanakan pada 26 Februari 2016 - 20 Mei 2016 di greenhouse dan Laboratorium Ekologi dan Produksi Tanaman Fakultas Peternakan dan Pertanian Universitas Diponegoro, Semarang.

\section{Materi}

Alat yang digunakan adalah polybag, timbangan manual, timbangan digital, kertas label, meteran, EC meter, jerigen, $\mathrm{pH}$ meter, stirer dan shaker, termometer ruang, cangkul, gunting, kertas, dan kamera. Bahan yang digunakan adalah 3 varietas kedelai (Dering 1, Demas 1, Devon 1), garam $\mathrm{NaCl}$, pupuk kandang, pupuk Urea, pupuk TSP, Pupuk KCl, tanah, air, plastik, dan amplop coklat.

\section{Metode}

Penelitian diawali dengan membuat larutan air penyiraman. Garam $\mathrm{NaCl}$ dilarutkan kedalam air dan diaduk menggunakan stirer. Kadar DHL diukur menggunakan EC meter dalam satuan $\mathrm{dS} / \mathrm{m}$. DHL air siraman berturut-turut adalah 3 $\mathrm{dS} / \mathrm{m}, 6 \mathrm{dS} / \mathrm{m}, 9 \mathrm{dS} / \mathrm{m}$. Media tanam yang digunakan adalah campuran tanah dan pupuk kandang. Tanah berasal dari lahan sekitar Kampus Fakultas Peternakan dan Pertanian Universitas Diponegoro pada kedalaman 1- $20 \mathrm{~cm}$ dengan $\mathrm{pH}$ 5,6 dan DHL $0.065 \mathrm{ds} / \mathrm{m}$. Tanah sebanyak $20 \mathrm{~kg}$ dimasukan kedalam polybag dan dicampur dengan pupuk kandang sapi $50 \mathrm{~g}$. Masing-masing polybag ditanam empat benih kedelai. Penyiraman menggunakan air keran untuk perlakuan K0 dan menggunakan larutan $\mathrm{NaCl}$ sesuai dosis untuk perlakuan K1, K2 dan K3. Penyiraman dilakukan dengan cara ditambahkan air sejumlah kapasitas 
lapang satu kali setiap sore hari. Pemupukan dilakukan sesuai dosis rekomendasi yaitu 135 $\mathrm{kg} / \mathrm{ha} \mathrm{TSP}, 100 \mathrm{~kg} / \mathrm{ha} \mathrm{KCl}$ dan $75 \mathrm{~kg} / \mathrm{ha}$ urea untuk setiap polybag. Pemupukan TSP dan $\mathrm{KCl}$ dilakukan bersamaan dengan penanaman sedangkan urea dilakukan pada saat penanaman, tiga minggu setelah tanam (MST) dan lima MST masing masing $1 / 3$ dari dosis rekomendasi. Penjarangan dilakukan pada minggu ketiga dengan menyisakan dua tanaman. Suhu dan kelembaban greenhouse di periksa dan dicatat setiap hari pada pagi, siang dan sore. Pemanenan dilakukan pada usia tanaman 10 minggu. Parameter pengamatan meliputi tinggi tanaman , jumlah daun, jumlah polong, berat polong, bobot 100 butir biji,

\section{Rancangan Percobaan dan Analisis Data}

Rancangan dasar yang digunakan dalam penelitian ini adalah Rancangan Acak Lengkap (RAL) pola faktorial 3x4 dengan empat ulangan. Faktor pertama adalah varietas kedelai (Dering 1 (V1), Demas 1 (V2), Devon 1 (V3)). Faktor kedua adalah tingkat salinitas air penyiraman (0 (K0), 3 (K1), 6 (K2), dan $9 \mathrm{dS} / \mathrm{m}$ (K3)). Data hasil pengamatan dianalisis keragamannya dan dilanjutkan dengan uji jarak berganda Duncan pada taraf $5 \%$.

\section{HASIL DAN PEMBAHASAN}

\section{Tinggi Tanaman}

Hasil uji jarak berganda Duncan (DMRT) perlakuan tingkat salinitas air penyiraman dan varietas yang berbeda pada tinggi tanaman disajikan pada Tabel 1.

Hasil DMRT menunjukkan bahwa perlakuan tanpa pemberian larutan garam $(0 \mathrm{dS} / \mathrm{m})$ pada tinggi tanaman varietas Dering 1 , Demas 1 dan Devon 1 berturut-turut adalah $54,33 \mathrm{~cm}, 60,53 \mathrm{~cm}$ dan 51,35 cm tidak berbeda nyata dengan perlakuan pemberian larutan garam dengan dosis $3 \mathrm{dS} / \mathrm{m}$ yang memiliki hasil masing-masing 52,31 $\mathrm{cm}, 50,15 \mathrm{~cm}$ dan 60,15 cm (Tabel 1). Hal ini menunjukkan bahwa ketiga varietas kedelai memiliki toleransi pada tinggi tanaman sampai tingkat salinitas air penyiraman $3 \mathrm{dS} / \mathrm{m}$ hingga minggu ke-4. Sedangkan pada tingkat salinitas 6 $\mathrm{dS} / \mathrm{m}$ dan $9 \mathrm{dS} / \mathrm{m}$ menunjukkan perbedaan nyata. Semakin tinggi tingkat salinitias air penyiraman semakin rendah tinggi tanaman. Hal tersebut mengindikasikan bahwa pada tingkat salinitas air penyiraman $6 \mathrm{dS} / \mathrm{m}$ tanaman kedelai mengalami cekaman osmotik akibat penyerapan $\mathrm{Na}$ dan $\mathrm{Cl}$ berlebih sehingga menghambat penyerapan ion $\mathrm{K}^{+}$. Kristiono et al. (2013) menyatakan penurunan penyerapan $\mathrm{K}$ diakibatkan sifat antagonis penyerapan $\mathrm{Na}$ dan $\mathrm{K}$ pada akar. Kurangnya $\mathrm{K}$

Tabel 1. Tinggi tanaman kedelai minggu ke-4 pada perlakuan empat tingkat salinitas air penyiraman.

\begin{tabular}{ccccc}
\hline \hline \multirow{2}{*}{ Tingkat Salinitas } & \multicolumn{3}{c}{ Varietas } & \multirow{2}{*}{ Rata-rata } \\
\cline { 2 - 3 } & Dering 1 & Demas1 & Devon1 & \\
\hline$------d S / m-----$ & $54.33^{\text {ab }}$ & $60.53^{\mathrm{a}}$ & $51.35^{\text {ab }}$ & $55.40^{\mathrm{a}}$ \\
0 & $52.31^{\mathrm{ab}}$ & $50.15^{\mathrm{abc}}$ & $60.15^{\mathrm{a}}$ & $54.20^{\mathrm{a}}$ \\
6 & $44.54^{\mathrm{bcd}}$ & $40.34^{\mathrm{cd}}$ & $47.06^{\mathrm{bc}}$ & $43.98^{\mathrm{b}}$ \\
9 & $28.13^{\mathrm{e}}$ & $27.19^{\mathrm{e}}$ & $34.31^{\mathrm{de}}$ & $29.88^{\mathrm{c}}$ \\
\hline Rata-rata & $44.83^{\mathrm{a}}$ & $44.55^{\mathrm{a}}$ & $48.22^{\mathrm{a}}$ & \\
\hline
\end{tabular}

- Superskrip yang berbeda pada kolom dan baris yang sama menunjukkan perbedaan yang nyata $(\mathrm{P}<0,05)$

- Superskrip yang berbeda pada kolom interaksi menunjukkan perbedaan yang nyata $(\mathrm{P}<0,05)$ 
menyebabkan terhambatnya pertumbuhan tanaman karena merupakan unsur penyusun jaringan tanaman. Kalium berperan dalam mempertahankan turgor sel dan aktivitas enzim (Xiong dan Zhu, 2001)

Hasil DMRT menyatakan perbedaan varietas kedelai tidak memberikan pengaruh nyata pada tinggi tanaman hingga minggu ke-4 (Tabel 1). Hal ini menunjukkan ketiga varietas memiliki toleransi dan tingkat adaptasi yang sama terhadap salinitas hingga minggu ke-4. Berdasarkan Ilustrasi 1 ketahanan ditunjukkan oleh varietas Dering 1 (V1) dimana pada tingkat salinitas air penyiraman $6 \mathrm{dS} / \mathrm{m}$ (K2) menjadi satu-satunya varietas yang tidak mengalami penurunan rerata tinggi dan pada tingkat salinitas $9 \mathrm{dS} / \mathrm{m}$ menjadi varietas yang mengalami penurunan rerata tinggi paling lama yaitu pada minggu ke-9. Dering 1 menjadi lebih toleran dari vareitas lain karena merupakan varietas yang memiliki ketahanan terhadap kekeringan. Salinitas menyebabkan terganggunya penyerapan air sehingga tanaman mengalami cekaman kekeringan. Hal tersebut sesuai dengan Bohnert (2007) yang menyatakan konsentrasi garam yang tinggi mampu meningkatkan tekanan osmotik sehingga menggangu penyerapan air oleh tanaman. Varietas Dering 1 mampu melakukan mekanisme ketahanan pada kondisi tercekam air dengan mengurangi kelebihan air melalui produksi ABA lebih banyak untuk menutup stomata. Suhartina dan Kuswantoro (2011) menyatakan pada kondisi tercekam air, akar varietas toleran menghasilkan
ABA lebih banyak dan diangkut melalui xylem menuju daun untuk menutup stomata dengan cara menghambat pompa proton.

\section{Jumlah Daun}

Hasil uji jarak berganda Duncan (DMRT) perlakuan tingkat salinitas air penyiraman dan varietas yang berbeda pada jumlah daun disajikan pada Tabel 2.

Hasil DMRT menunjukkan bahwa perlakuan tanpa pemberian larutan garam $(0 \mathrm{dS} / \mathrm{m})$ pada jumlah daun varietas Dering 1 , Demas 1 dan Devon 1 berturut-turut adalah 6,75, 7 dan 5,63 tidak berbeda nyata dengan perlakuan pemberian larutan garam dengan dosis $3 \mathrm{dS} / \mathrm{m}$ yang memiliki hasil masing-masing $5,63,5,63, \mathrm{~cm}$ dan $6,38 \mathrm{~cm}$ (Tabel 2). Hal ini menunjukkan bahwa ketiga varietas kedelai memiliki toleransi terhadap jumlah daun pada tingkat salinitas air penyiraman $3 \mathrm{dS} / \mathrm{m}$ hingga minggu ke-4. Hal tersebut disebabkan karena pada tingkat salinitas air penyiraman $3 \mathrm{dS} / \mathrm{m}$ tanaman belum mengakumulasi garam $\mathrm{Na}$ terlalu tinggi sehingga daun masih mampu tumbuh normal dan belum mengalami gugur akibat nekrosis. Menurut Mun dan Tester (2008) kerusakan daun merupakan fase lambat cekaman salinitas yang terjadi akibat akumulasi $\mathrm{Na}^{+}$dalam daun dari waktu ke waktu.

Sedangkan pada tingkat salinitas air penyiraman $6 \mathrm{dS} / \mathrm{m}$ dan $9 \mathrm{dS} / \mathrm{m}$ menunjukkan perbedaan nyata dibandingkan dengan $0 \mathrm{ds} / \mathrm{m}$ (Tabel 2). Hal tersebut menunjukkan bahwa pada

Tabel 2. Jumlah daun tanaman kedelai minggu ke-4 pada perlakuan empat tingkat salinitas air penyiraman.

\begin{tabular}{ccccc}
\hline \hline \multirow{2}{*}{ Tingkat Salinitas } & \multicolumn{3}{c}{ Varietas } & \multirow{2}{*}{ Rata-rata } \\
\cline { 2 - 3 } & Dering 1 & Demas 1 & Devon 1 & \\
\hline$-----(\mathrm{dS} / \mathrm{m})------$ & & & & \\
0 & $6.75^{\mathrm{a}}$ & $7.00^{\mathrm{a}}$ & $5.63^{\mathrm{abc}}$ & $6.46^{\mathrm{a}}$ \\
3 & $5.63^{\mathrm{abc}}$ & $5.63^{\mathrm{abc}}$ & $6.38^{\mathrm{a}}$ & $5.88^{\mathrm{ab}}$ \\
6 & $5.75^{\mathrm{ab}}$ & $4.75^{\mathrm{bcd}}$ & $5.38^{\mathrm{abc}}$ & $5.29^{\mathrm{b}}$ \\
9 & $4.50^{\mathrm{bcd}}$ & $3.75^{\mathrm{d}}$ & $4.13^{\mathrm{cd}}$ & $4.13^{\mathrm{c}}$ \\
\hline Rata-rata & $5.66^{\mathrm{a}}$ & $5.28^{\mathrm{a}}$ & $5.38^{\mathrm{a}}$ & \\
\hline
\end{tabular}

- Superskrip yang berbeda pada kolom dan baris yang sama menunjukkan perbedaan yang nyata $(\mathrm{P}<0,05)$

- Superskrip yang berbeda pada kolom interaksi menunjukkan perbedaan yang nyata $(\mathrm{P}<0,05)$ 
tingkat salinitas air penyiraman $6 \mathrm{dS} / \mathrm{m}$ dan 9 $\mathrm{dS} / \mathrm{m}$ pertumbuhan tanaman mulai terganggu dikarenakan menurunnya kemampuan menyerap nitrogen. Berkurangnya penyerapan $\mathrm{K}$ menurunkan aktifitas enzim nitrat reductase $(\mathrm{Hu}$ dan Schmidhalter, 2005). Enzim nitrat reductase berperan dalam mengubah $\mathrm{NO}_{3}$ menjadi $\mathrm{NH}_{3}$. Nitrogen berperan penting dalam pembentukan daun. Mudgal (2004) menyatakan bahwa pada kondisi salin akan menggangu pengikatan nitrogen yang disebabkan oleh penurunan kanduangan leghemoglobin dalam bintil akar dan aktivitas nitrat reductase.

Hasil DMRT menyatakan perbedaan varietas kedelai pada perlakuan yang diberikan tidak memberikan pengaruh nyata pada jumlah daun hingga minggu ke-4 (Tabel 2). Hal tersebut menunjukkan ketiga varietas memiliki tingkat toleransi yang sama hingga minggu ke-4. Tingkat toleransi yang sama mungkin disebabkan karakter morfologi yang hampir sama antara ketiga varietas yang diujikan. Berdasarkan Deskripsi Varietas Kedelai Balitkabi (2016) varietas Dering 1, Demas 1 dan Devon 1 memiliki umur berbunga, umur panen, tipe pertumbuhan dan jumlah percabangan yang hampir sama. Selain itu minggu ke-4 diduga tanaman belum memasuki fase kritis cekaman salinitas. Fase kritis ditandai dengan daun mulai mengalami kerusakan akibat nekrosis. Nekrosis daun disebabkan oleh toksisitas akibat akumulasi $\mathrm{Na}^{+}$dalam daun. Jouyban (2012) menyatakan akumulai ion $\mathrm{Na}^{+}$menjadi penyebab utama kerusakan tanaman pada cekaman salinitas.

\section{Jumlah Polong per Tanaman}

Hasil uji jarak berganda Duncan (DMRT) perlakuan tingkat salinitas air penyiraman dan vaietas yang berbeda pada jumlah polong disajikan pada Tabel 3.

Hasil DMRT menunjukkan bahwa perlakuan tingkat salinitas air penyiraman memberikan pengaruh nyata pada jumlah polong per tanaman (Tabel 3). Tingkat salinitas $0 \mathrm{dS} / \mathrm{m}$ memberikan hasil tertinggi dengan rerata 41,42 polong per tanaman, berbeda nyata dengan tingkat salinitas 3 , 6 , dan $9 \mathrm{dS} / \mathrm{m}$ dengan rerata berturut-turut 21,92 , 4,50, dan 0,21 polong per tanaman. Hasil perlakuan tingkat salinitas yang berbeda menunjukkan bahwa tiap varietas tidak mampu memproduksi jumlah polong setara dengan

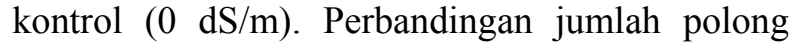
dapat dilihat pada ilustrasi 3. Hal tersebut disebabkan pada stadia pembentukan polong, daun telah mengalami kerusakan akibat akumulasi $\mathrm{Na}$ sehingga menggangu proses fotosintesis. Akumulasi $\mathrm{Na}^{+}$dalam daun yang terjadi dari waktu ke waktu bersifat toksik (Munns dan Tester, 2008). Purwaningrahayu (2013) menyatakan cekaman salinitas membatasi produksi polong dan biji tanaman. Pada salinitas 9 $\mathrm{ds} / \mathrm{m}$ sebagian besar tanaman telah mati sebelum stadia pembentukan polong.

Hasil DMRT menunjukkan bahwa perlakuan varietas tidak memberikan pengaruh nyata pada jumlah polong per tanaman (Tabel 3). Hasil

Tabel 3. Jumlah polong per tanaman kedelai pada perlakuan empat tingkat salinitas air penyiraman.

\begin{tabular}{ccccc}
\hline \hline \multirow{2}{*}{ Tingkat Salinitas } & \multicolumn{3}{c}{ Varietas } & \multirow{2}{*}{ Rata-rata } \\
\cline { 2 - 3 } & Dering 1 & Demas 1 & Devon 1 & \\
\hline $\mathrm{dS} / \mathrm{m}$ & $33.63^{\mathrm{bc}}$ & $50.38^{\mathrm{a}}$ & $40.25^{\mathrm{ab}}$ & $41.42^{\mathrm{a}}$ \\
0 & $22.63^{\mathrm{cd}}$ & $22.88^{\mathrm{d}}$ & $20.25^{\mathrm{d}}$ & $21.92^{\mathrm{b}}$ \\
3 & $10.75^{\mathrm{e}}$ & $0.75^{\mathrm{f}}$ & $2.00^{\mathrm{f}}$ & $4.50^{\mathrm{c}}$ \\
6 & $0.63^{\mathrm{f}}$ & $0.00^{\mathrm{f}}$ & $0.00^{\mathrm{f}}$ & $0.21^{\mathrm{d}}$ \\
9 & $16.91^{\mathrm{a}}$ & $18.50^{\mathrm{a}}$ & $15.63^{\mathrm{a}}$ & \\
\hline Rata-rata & & & & \\
\hline
\end{tabular}

- Superskrip yang berbeda pada kolom dan baris yang sama menunjukkan perbedaan yang nyata $(\mathrm{P}<0,05)$

- Superskrip yang berbeda pada kolom interaksi menunjukkan perbedaan yang nyata $(\mathrm{P}<0,05)$ 
jumlah polong tertinggi ialah varietas Demas 1 dengan rerata 18,50 polong per tanaman namun tidak berbeda nyata dengan varietas Dering 1 dan Devon 1 dengan rerata masing-masing 16,91 dan 15,63 polong per tanaman. Hal ini menunjukkan bahwa varietas yang diujikan mampu memproduksi jumlah polong yang sama pada perlakuan cekaman salinitas. Namun dapat dihitung pula persentase penurunan jumlah polong tiap varietas pada tiap tingkat salinitas air penyiraman dengan membandingkannya terhadap kontrol. Varietas Dering 1 mengalami penurunan jumlah polong $32,7,68,03$, dan $98,10 \%$ pada tingkat salinitas 3, 6, dan $9 \mathrm{dS} / \mathrm{m}$, varietas Demas 54,5 , 98,5 dan 100\%, varietas Devon 49,7, 95,03 , dan 100\%. Berdasarkan persentase penurunan tersebut, varietas Dering 1 memiliki hasil penurunan terkecil dibanding varietas Demas 1 dan Devon 1. Hasil varietas Dering 1 lebih toleran juga ditunjukkan oleh hasil interaksi uji jarak berganda Duncan yaitu pada tingkat salinitas $3 \mathrm{dS} / \mathrm{m}$ dengan nilai 22,63 polong per tanaman tidak berbeda nyata dengan hasil rerata kontrol 33,63 polong per tanaman. Hal ini menunjukkan bahwa varietas Dering 1 memiliki toleransi lebih tinggi terhadap tingkat salinitas. Toleransi yang terjadi dikarenakan Dering 1 memiliki sifat toleran kekeringan selama fase reproduktif. Suhartina dan Kuswantoro (2011) menyatakan kedelai yang toleran kekeringan saat fase reproduktif mampu mengurangi kerontokan bunga sehingga mampu melanjutkan hingga fase pembentukan polong lebih baik dari varietas kedelai yang tidak toleran.

\section{Berat Polong per Tanaman}

Hasil uji jarak berganda Duncan (DMRT) perlakuan tingkat salinitas air penyiraman dan varietas yang berbeda pada berat polong disajikan pada Tabel 4.

Hasil DMRT menunjukkan bahwa perlakuan tingkat salinitas air penyiraman memberikan pengaruh nyata pada berat polong per tanaman (Tabel 4). Tingkat salinitas $0 \mathrm{dS} / \mathrm{m}$ memberikan hasil tertinggi dengan rerata 23,68 g per tanaman, berbeda nyata dengan tingkat salinitas 3, 6, dan 9 $\mathrm{dS} / \mathrm{m}$ dengan rerata berturut-turut $8,52 \mathrm{~g}, 0,90 \mathrm{~g}$ dan $0,01 \mathrm{~g}$ per tanaman. Penurunan hasil sejalan dengan semakin tinggi tingkat salinitas menunjukkan bahwa salinitas nyata menurunkan berat polong per tanaman. Hal tersebut terjadi karena cekaman salinitas menggangu stadia pengisian polong. Ahmed (2009) menyatakan salinitas menyebabkan terhambatnya pemasakan polong.

Hasil DMRT menunjukkan bahwa perlakuan varietas tidak memberikan pengaruh nyata pada berat polong per tanaman (Tabel 4). Hal ini menunjukkan bahwa tiap varietas mampu menghasilkan total berat polong yang sama pada perlakuan salinitas. Namun dapat dihitung pula persentase penurunan berat polong tiap varietas pada tiap tingkat salinitas air penyiraman dengan membandingkannya terhadap kontrol yaitu varietas Dering 1 mengalami penurunan berat polong $55,8,88,5$ dan $99,8 \%$ pada tingkat

Tabel 4. Berat polong per tanaman kedelai pada perlakuan empat tingkat salinitas air penyiraman.

\begin{tabular}{ccccc}
\hline \hline \multirow{2}{*}{ Tingkat Salinitas } & \multicolumn{3}{c}{ Varietas } & \multirow{2}{*}{ Rata-rata } \\
\cline { 2 - 3 } & Dering 1 & Demas 1 & Devon1 & \\
\hline $\mathrm{dS} / \mathrm{m}$ & $-----------\mathrm{g}----------$ & \\
0 & $19.86^{\mathrm{a}}$ & $23.56^{\mathrm{a}}$ & $27.64^{\mathrm{a}}$ & $23.68^{\mathrm{a}}$ \\
3 & $8.78^{\mathrm{b}}$ & $7.46^{\mathrm{b}}$ & $9.31^{\mathrm{b}}$ & $8.52^{\mathrm{b}}$ \\
6 & $2.28^{\mathrm{c}}$ & $0.21^{\mathrm{c}}$ & $0.22^{\mathrm{c}}$ & $0.90^{\mathrm{c}}$ \\
9 & $0.04^{\mathrm{c}}$ & $0.00^{\mathrm{c}}$ & $0.00^{\mathrm{c}}$ & $0.01^{\mathrm{c}}$ \\
\hline Rata-rata & $7.74^{\mathrm{a}}$ & $7.81^{\mathrm{a}}$ & $9.29^{\mathrm{a}}$ & \\
\hline
\end{tabular}

- Superskrip yang berbeda pada kolom dan baris yang sama menunjukkan perbedaan yang nyata $(\mathrm{P}<0,05)$

- Superskrip yang berbeda pada kolom interaksi menunjukkan perbedaan yang nyata $(\mathrm{P}<0,05)$ 
salinitas 3, 6, dan $9 \mathrm{dS} / \mathrm{m}$, varietas Demas 168 , 99,19 dan 100\%, varietas Devon 1 66,3 , 99,2, dan $100 \%$. Berdasarkan persentase penurunan tersebut, varietas Dering 1 memiliki presentase penurunan hasil terkecil dibandingkan varietas Demas 1 dan Devon 1. Hal tersebut mungkin terjadi karena varietas dering tidak mengakumulasi banyak garam $\mathrm{Na}$ pada daun sehingga kerusakaan atau penuaan daun terjadi lebih lambat dari varietas lain. Cabot et al. (2014) menyatakan cekaman salinitas menyebabkan penuaan daun lebih cepat sehingga menurunkan hasil biji yang berakibat turunnya berat polong.

\section{Bobot 100 biji}

Hasil uji jarak berganda Duncan (DMRT) perlakuan tingkat salinitas dan vaietas yang berbeda pada bobot 100 biji disajikan pada Tabel 5.

Hasil DMRT menunjukkan bahwa perlakuan tingkat salinitas air penyiraman memberikan pengaruh nyata pada bobot 100 biji (Tabel 5). Bobot 100 biji pada perlakuan tingkat salinitas 3, 6 dan $9 \mathrm{dS} / \mathrm{m}$ turun secara linier dibandingkan dengan perlakuan kontrol $0 \mathrm{ds} / \mathrm{m}$ (Ilustrasi 4). Hal tersebut terjadi karena cekaman salinitas menyebabkan daun mengalami kerusakan lebih cepat. Kerusakan daun akan berakibat menurunnya fotosintesis sehingga menyebabkan produksi menjadi terganggu. Hal tersebut sesuai dengan Ghassemi-Golezani et al. (2011) yang menyatakan penurunan hasil biji disebabkan rendahnya indeks klorofil daun dan aktivitas fotosistem II, serta tingginya kadar prolin.

Hasil DMRT menunjukkan bahwa perlakuan varietas memberikan pengaruh nyata pada bobot 100 biji (Tabel 5). Diketahui varietas Dering 1 berbeda nyata dengan varietas Demas 1 dan Devon 1. Dering 1 yang merupakan kedelai berbiji sedang memiliki bobot 100 biji lebih tinggi dari Devon 1 yang berbiji besar. Hal tersebut menunjukkan bahwa tingkat salinitas mempengaruhi ukuran biji menjadi lebih kecil. Ahmed (2009) menyatakan cekaman salinitas menyebabkan biji menjadi kisut dan keriput.

Varietas Dering 1 mengalami penurunan bobot 100 biji 42,4, 77,1 dan 99\% pada tingkat salinitas 3, 6, dan $9 \mathrm{dS} / \mathrm{m}$, varietas Demas 1 67,7, 95,6, dan 100\%, varietas Devon 158,100 , dan $100 \%$. Varietas Dering 1 mengalami penurunan produksi kurang dari $50 \%$ pada tingkat salinitas air penyiraman $3 \mathrm{dS} / \mathrm{m}$ atau pada akumulasi salinitas tanah $1,14 \mathrm{dS} / \mathrm{m}$. Penurunan hasil biji sebesar $50 \%$ dapat dikategorikan sebagai batas kritis toleransi tanaman terhadap cekaman salinitas (Krisnawati dan Adie, 2009). Varietas Dering 1 memiliki bobot 100 biji lebih baik karena mekanisme terhadap cekaman kekeringan yang dimiliki membuat kerusakan daun yang terjadi tidak lebih parah dari varietas lain yang diujikan. Sehingga mampu melakukan proses fotosintesis dan menghasilkan biji yang lebih baik. Keruskan daun menyebabkan tanaman tidak

Tabel 5. Bobot 100 biji tanaman kedelai pada perlakuan empat tingkat salinitas air penyiraman.

\begin{tabular}{|c|c|c|c|c|}
\hline \multirow{2}{*}{ Tingkat Salinitas } & \multicolumn{3}{|c|}{ Varietas } & \multirow{2}{*}{ Rata-rata } \\
\hline & Dering 1 & Demas 1 & Devon 1 & \\
\hline $\mathrm{dS} / \mathrm{m}$ & \multicolumn{3}{|c|}{ 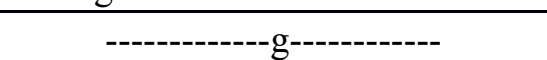 } & \\
\hline 0 & $5.47^{\mathrm{a}}$ & $4.36^{\mathrm{a}}$ & $4.71^{\mathrm{a}}$ & $4.85^{\mathrm{a}}$ \\
\hline 3 & $3.15^{\mathrm{b}}$ & $1.41^{\mathrm{c}}$ & $1.98^{\mathrm{c}}$ & $2.18^{\mathrm{b}}$ \\
\hline 6 & $1.25^{\mathrm{c}}$ & $0.19^{d}$ & $0.00^{\mathrm{d}}$ & $0.48^{\mathrm{c}}$ \\
\hline 9 & $0.05^{\mathrm{d}}$ & $0.00^{\mathrm{d}}$ & $0.00^{\mathrm{d}}$ & $0.02^{\mathrm{d}}$ \\
\hline Rata-rata & $2.48^{\mathrm{a}}$ & $1.49^{\mathrm{b}}$ & $1.67^{\mathrm{b}}$ & \\
\hline
\end{tabular}

- Superskrip yang berbeda pada kolom dan baris yang sama menunjukkan perbedaan yang nyata $(\mathrm{P}<0,05)$

- Superskrip yang berbeda pada kolom interaksi menunjukkan perbedaan yang nyata $(\mathrm{P}<0,05)$ 
mampu melakukan proses fotosintesis. Laju fotosintesis pada tanaman tercekam salin rendah diakibatkan konsentrasi $\mathrm{CO}^{2}$ pada kloroplas menurun karena berkurangnya konduktansi stomata (Gama et al., 2007).

\section{KESIMPULAN}

Berdasarkan hasil penelitian dapat disimpulkan tanaman kedelai mengalami penurunan pertumbuhan dan produksi sejalan dengan meningkatnya tingkat salinitas air penyiraman. Pertumbuhan dan produksi kedelai varietas Dering 1 memiliki potensi ketahanan yang lebih baik dibanding Demas 1 dan Devon 1.

\section{DAFTAR PUSTAKA}

Ahmed, S. 2009. Effect of salinity on the yield and yield component of mungbean. Pak. J. Bot. 41(1): 263-268.

Badan Pusat Statistik. 2015. Susenas 2015 : Konsumsi Kalori dan Protein Penduduk Indonesia dan Provinsi. Badan Pusat Statistik, Jakarta.

Balitkabi. 2016. Deskripsi Varietas Unggul Kedelai 1918 - 2016. Balai Penelitian Tanaman Aneka Kacang dan Umbi, Malang.

Bohnert, H.J. 2007. Abiotic Stress. John Wiley \& Sons, Ltd.

Cabot, C., J. V. Sibole, J. Barcelo, and C. Poschenrieder. 2014. Lesson from crops plants struggling with salinity. Plant Science 226: 2-13.

Chinnusamy, V., A. Jagendorf, and J.K. Zhu. 2005. Understanding and improving salt tolerance in plants. Crop Sci. 45:437-448.

Gama, P.B.S., S. Inanaga, K. Tanaka, and R. Nakazawa. 2007. Physiological response of common bean (Phaseolus vulgaris $\mathrm{L}$.) seedlings to salinity stress. Afr. J. Biotechnol. 6 (2) : 79-88.
Ghassemi-Golezani, K., M. Taifeh-Noori, S. Oustan, M. Moghaddam and S. S. Rahmani. 2011. Physiological performance of soybean cultivars under salinity stress. J. of Plant Physiol. and Breeding 1(1):1-7.

Hu, Y. and U. Schmidhalter. 2005. Drought and salinity: a comparison of their effects on mineral nutrition of plants. J. Plant Nutr. Soil Sci. 168:541- 549.

Jouyban, Z. 2012. The effects of salt stress on plant growth. Tech. J. Engin \& App Sci. 2(1): 7-10.

Kementerian Pertanian. 2015. Rencana Strategis Pembangunan Tanaman Pangan Tahun 2015-2019. Direktorat Jenderal Tanaman Pangan. Jakarta.

Krisnawati, A., dan M. M. Adie. 2009. Kendali genetik dan karakter penetu toleransi kedelai terhadap salinitas. Iptek Tanaman Pangan 4 (2) : 222- 235.

Kristiono, A., R. D. Purwaningrahayu, dan A. Taufiq. 2013. Respon tanaman kedelai, kacang tanah dan kacang hijau terhadap cekaman salinitas. Buletin Palawija. 26 : $45-60$. .

Mudgal, V. 2004. Physiological studies on growth and nitrogen metabolism in Cicer arietinum L. under saline conditions. Rohilkhand University, India. (Thesis)

Munns, R. and M. Tester. 2008. Mechanism of salinity tolerance. Annu. Rev. Plant Biol. 59 :651-681.

Outlook Komoditas Pertanian Subsektor Tanaman Pangan: Kedelai. 2016. Pusat Data dan Sistem Informasi Kementrian Pertanian, Jakarta.

Purwaningrahayu, R. D. 2016. Karakter morfofisiologis dan agronomi kedelai toleran salinitas. J. Iptek Tanaman Pangan $11(1)$ : 35-48. 
Rachman, A., I.G.M. Subiksa, dan Wahyunto. 2013. Teknik Produksi dan Pengembangan Kedelai : Perluasan Areal Tanaman Kedelai ke Lahan Suboptimal. Balai Penelitian Tanaman Kacang- Kacangan dan UmbiUmbian, Malang.

Suhartina dan H. Kuswantoro. 2011. Pemuliaan tanaman kedelai toleran terhadap kekeringan. Bul. Palawija 21: 26-38.
Taufiq, A. 2014. Identifikasi Masalah Keharaan Tanaman Kedelai. Balai Penelitian Tanaman Aneka Kacang dan Umbi, Malang.

Xiong, L., and J.K. Zhu. 2001. Abiotic stress signal transduction in plants: Molecular and genetic perspectives. Physiol Plant 112 : 152-168. 